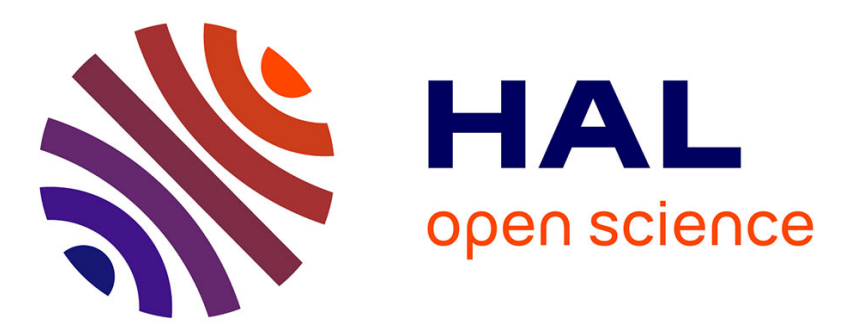

\title{
Beyond Conditionality: EU Enlargement, European Party Federations and the Transnational Activity of German Political Foundations
}

Dorota Dakowska

\section{- To cite this version:}

Dorota Dakowska. Beyond Conditionality: EU Enlargement, European Party Federations and the Transnational Activity of German Political Foundations. Perspectives on European Politics and Society, 2002, 3 (2), pp.271-296. halshs-00288964

\section{HAL Id: halshs-00288964 \\ https://shs.hal.science/halshs-00288964}

Submitted on 16 Aug 2015

HAL is a multi-disciplinary open access archive for the deposit and dissemination of scientific research documents, whether they are published or not. The documents may come from teaching and research institutions in France or abroad, or from public or private research centers.
L'archive ouverte pluridisciplinaire $\mathbf{H A L}$, est destinée au dépôt et à la diffusion de documents scientifiques de niveau recherche, publiés ou non, émanant des établissements d'enseignement et de recherche français ou étrangers, des laboratoires publics ou privés. 
Dorota Dakowska, «Beyond Conditionality: EU Enlargement, European Party Federations and the Transnational Activity of German Political Foundations ", Perspectives on European Politics and Society, vol. $3, \mathrm{n}^{\circ} 2,2002$, p. 271-296.

Dorota Dakowska

\section{BEYOND CONDITIONALITY: EU ENLARGEMENT, EUROPEAN PARTY FEDERATIONS AND THE TRANSNATIONAL ACTIVITY OF GERMAN POLITICAL FOUNDATIONS}

This article deals with the mechanisms and impact of the enlargement process on the identity evolution of Polish political elites. This process is closely related to the evolution of EU governance, for associating new political partners will have - and have already had - an impact on the decision making process at different levels of the EU. Starting with theoretical approaches of the EU's normative impact on the prospective members' political parties (I), discussing the analytical conceptualisations of the European party federations' enlargement and the interrelationship between the logic of appropriateness and the logic of expected consequences (II), the article deals with the case of a non-governmental actor, German political foundations which have been particularly active in the field of transnational political communication between the party federations and the political parties from the candidate countries during the pre-accession period (III). The empirical evidence calls into question the notion of conditionality as the major explaining factor of the EU-induced change. 
While the impact of the EU enlargement process on polities and policies of the candidate countries has been extensively analysed in the context of ongoing accession negotiations and the overtaking of the acquis communautaire, the question of the impact of enlargement on the political structures of interest representation (the politics dimension) remains marginal.

However, there can be no doubt that the European Union is having a profound impact on the domestic political patterns of the candidate states. The adaptation to the acquis communautaire, and the overtaking of legal and institutional solutions in a context of conditionality, has led some analysts to qualify the institutional transfer linked to it as imitation $^{1}$. More and more researchers perceive the ongoing enlargement as part of the Europeanisation process, which at the beginning was broadly considered as earmarked for EU member countries, directly involved in the community rules. Still, Europeanisation is not synonymous with convergence and its inputs diverge depending, among other things, on institutional backgrounds ${ }^{2}$. Candidate countries adapt differently to EU pressures, according to their institutional past, structure of civil society, and perceptions of the opportunity structures in the EU.

This paper deals with a process, which may be called the Europeanisation of Polish political parties during their association to European party federations in the 1990s. To be more precise, the studied rule of European governance is the role of political parties at European level and the way in which the extension of European governance to Central and Eastern European Countries (CEEC) affects the perceptions and activities of party leaders from the candidate countries. By the term "role of political parties at EU level" is understood the interaction between different national parties within European party federations (characterised either by consensus building or dissent, the politicisation or depoliticisation of certain issues), which has been conceptualised as networking, the building of nodal points of contacts 
between party organisations. Political parties are actors in the process of searching for new partners from CEEC and their legitimisation on the European arena. As factors of integration, they become important channels of European norms and rules.

The enlargement pressures analysed do not refer to legal solutions or policy paradigms. On the contrary, they concern mainly immaterial elements relative to identity and perceptions of political elites, which makes the exact measure of the degree of change difficult.

Numerous analysts have noted that European integration may be conceptualised as a process of social construction. However, empirical research drawing on constructivist and sociological insights has remained a "poor relation" to European studies. It acquired its place in the theoretical reflection ${ }^{3}$ or in hypothesis building on a macro scale; however, few researchers deigned to venture empirically onto the fields of norm diffusion to observe mechanisms of Europeanisation taking place on a micro scale. Thus, adjusting the focus to the transnational scale (parties, interest groups, transgovernmental actors or administrative subgroups), and especially paying attention to social learning processes could allow a finer analysis of the interactions taking place between the applicant and the EU institutions.

The EU enlargement may be analysed as a process of international socialisation to liberal norms ${ }^{4}$, therefore its study should encompass not only the "hard" elements of the transfer (rules, paradigms, ways of doing), but also the "soft" elements: ideas, beliefs, formal and informal norms ${ }^{5}$. While focusing on political party elites, we ask the question of mechanisms, which influence perceptions, discourses and political decisions and their evolution over time.

This article argues that Eastern Enlargement at the party level may be seen as a two-sided process, affecting both candidate state political parties and the parties at EU level. Political leaders from the candidate countries tend to be recognised by their European partners and to benefit from their material, but above all, nonmaterial resources. Party leaders in the 
European Parliament perceive their interlocutors from CEEC as future partners and allies, which could help them to overcome certain internal crises. In studying the mechanisms of compliance to EU rules and norms, this paper shows that EU enlargement makes difficult a distinction between the logic of appropriateness and the logic of consequentiality. Drawing both on theoretical, institutionalist perspectives and on empirical evidence, it explains the way in which both these logics interfere with each other.

The aim of this case study is to throw light not so much on the essence of the CEEC party association process to European federations - which may be considered as marginal in the enlargement process, as compared to more visible legal or institutional transfers - but rather on its mechanisms. The delimitation of the empirical ground enables us to ask questions about the logic, channels, actors and instruments of change. It is obviously risky today to hypothesise about the impact of enlargement (politicians from the candidate states do not participate yet in collective decision-making within EU institutions). However, a few hypotheses can be made concerning the eventual impact of the analysed evolutions, with the reservation that they should be checked in the years to come, in a factually and not only hypothetically enlarged European Union

\section{The EU enlargement impact on the political party leaders - conditions and variables.}

Out of a range of actors, supranational, national, subnational, public and private, participating in the enlargement "composite" policy ${ }^{6}$, the European Parliament and the party federations are not considered the most influential. Attention is generally directed toward the European Commission, which managed to assert its leading position in the Enlargement policy from the 
beginning of the transformation process in $\mathrm{CEEC}^{7}$. Macro-policy and major or historic decisions are taken by representatives of the national governments during summits ${ }^{8}$.

This paper focuses on a rarely analysed channel of transfer of EU norms and informal rules: the party network close to the European Parliament. Choosing to study the EU enlargement impact through the prism of political parties may seem paradoxical: On the one hand, party structures at the European level are known to have a limited impact on EU governance. The resources and the weight of parties in the European system are weak when compared to national parties ${ }^{9}$. Their legal position is far from being clear, notwithstanding the efforts made to underline the role played by European "parties" in the Maastricht Treaty. ${ }^{10}$ The European Parliament has remained a marginal institution in the EU governance nexus, although it has acquired more competences in the past few years. "The transnational party federations which were formed prior to the EP elections have been nothing more than clearing houses, providing information campaign materials and organising poorly attended conferences and candidate exchanges. Under the present institutional system the EP elections will only be 'second order national contests","11.

On the other hand, however, the "European Union is run by party politicians" 12 . Be it in Commission Directorates, the Council of Ministers or the European Council, most of the European leaders originate from political parties of the member states. Moreover, the enlargement context forces European party leaders to rethink the criteria applied to the candidates and the implications of the reforms to come on decision-making in the EU. Therefore, "when a new country applies to join the EU, a long hard look is taken at its political parties and at its capacity to sustain a stable but competitive party system"13. Thus, enlargement at the party level may be seen as a two-sided process, affecting both CEEC 
parties and the party federations at the European level but also, eventually, European governance. "The EU confronts domestic political parties with a new structure of threats and opportunities. They have to adopt to the EU and organise themselves for participation in its institutions and rule-making, if they are to maintain their influence over all the political process that shape the distribution of values in their own national societies"14. Thus, the observation of everyday interactions between political elites from the EU and from candidate states gives us an important insight into the non-material side of the enlargement process.

\section{The analysed rule: party networking at the EU level}

The model of transnational interactions between EU parties reflects a specificity of European governance, which consists in bringing together actors from different levels, both national and supranational. According to Robert Ladrech, "the activities of transnational parties, EP party groups and national parties together constitute networks of partisan activity building points of contacts that bring national parties into cooperation with European actors on issues that are important to each side" ${ }^{\prime 15}$. An essential function of transnational party cooperation has been the integration of national parties in the EU in order to elaborate a common programme on the general orientations of European integration "in an effort to socialise important anti-European parties"16. Thus, political party federations and the European parliamentary groups have different functions from those of classical parliamentary and party politics, while contributing to the transformation of the EU political system. This paper explores the relations installed by the European party federations with CEEC parties as socialisation channels, which open the way to the Europeanisation of the latter.

The impact of the evolution of political party networking on EU governance 
For Ladrech, "The EP may be seen as a nexus or site for a network of partisan organisations which exist within the EP - party groups - and outside of it - national parties and transnational party federations. Their contribution to EU political governance is less significant for the details of EP legislative work than in shaping the EU's medium-to-longterm issue agenda..."17. In the context of the 1996-97 Inter-Governmental Conference, the author shows an increase of party networking, with transnational parties operating as intermediaries between the national parties and EP party groups. There is also evidence of growing involvement of party federations in socio-economic issues through the party leader summits ${ }^{18}$, which may be observed both at the party-to-party level (party leaders' summits, working groups) and at the institutional level (EP committees, national parliaments). This kind of instrumental attitude to the European party networks may contribute to the legitimisation of the EU as a "pragmatic problem-solving arena"19. Ladrech advances three measures through which the agenda-setting activity of transnational political parties affects governance in the EU: 1.) It reinforces the continued party networking; 2.) In accentuating the socio-economic cleavages it may help legitimating the EU polity; 3.) It favours the perception of Brussels by the party elites as an arena for consensus building and coordination rather than competition.

The case of political party interaction at the European level seems an ideal laboratory to observe the transfer of normative elements embedded in party organisations' identity. While concentrating on European party federations, this article argues they should be seen as part of the triple party organisation, which also include the EP parliamentary groups and the national parties $^{20}$. Social change entailed by Enlargement is too often identified with the activity of national governments or the European Commission. These institutions require compliance; indeed, they check and threaten, however they concentrate more on the control of legal 
adaptation than on norm interiorisation. The Commission is studied, rather, in the light of its material bargaining power as opposed to its social influence. This article argues that social change may be triggered by an institution considered "a backwater of Europeanisation" 21 , in this case, the European Parliament and related party networks.

In the following sections empirical evidence is provided to explain the mechanisms of Europeanisation (or the way in which the EU exercises its influence on the candidate state parties). The following hypotheses characterise the enlargement process:

1. Causal mechanisms: the logic of appropriateness and the logic of consequentiality coexist. Thus, the analytical challenge consists less in defining which of the mentioned logics dominates a process, but rather how they interfere with each other, at what moments the one prevails over the other, and how this evolution can be explained.

2. The essence of the process: focalising on generating compliance presents enlargement as a one-side process, giving no other way for the candidate side to adapt (or remain outside). Of course, the asymmetry of the EU / applicants relationship cannot be contradicted. Still, reducing the study of European influence to conditionality leaves little room to analyse the diversity of the impact and also the possible instrumentalisation of EU pressures through agents from $\mathrm{CEEC}^{22}$.

3. Actors: focusing on bureaucratic or governmental actors provides only a partial insight on the impact of EU governance outside the Union, especially as far as the normative pressures and social learning are concerned. Focusing the analysis on (not necessarily governmental) political actors, be they party leaders or representatives of party related foundations, throws new light on EU external governance. Generating compliance with EU norms may be a matter of socialising institutions such as party organisations. 


\section{What is not the point of this paper?}

This paper does not aim to study the impact of enlargement on the party system in CEEC, although it is obvious that the EU influences national cleavages and forces domestic parties to adopt new logics of action while confronting them with a changing structure of political opportunities $^{23}$. However, even if the EU variable plays strongly on the building of new cleavages, it seems difficult to isolate this variable as having a decisive influence on the format and mechanisms of political parties ${ }^{24}$. Many other domestic factors (local particularities, genetic factors, the transformation context) influence the building of new parties in CEEC. Thirteen years after the beginning of political negotiations leading to the end of Soviet domination in the region, the political landscape in some countries is still exposed to frequent recompositions.

This paper does not deal with "nation state identity" as mirrored in the discourse of political

elites ${ }^{25}$. The span of one decade seems too limited to advance conclusions about a general redefinition of the state identity. Moreover, discourse analysis alone cannot account for a full explanation of identities' change. In a fluctuating political context, discourses evolve and are often instrumentalised with the aim of internal or external legitimisation. Therefore, looking for norms and ideas, we should concentrate not only on the official, but also on the unofficial discourses and political decisions. The analysis of norm diffusion requires the use of a larger number of methodological tools, encompassing both in-depth interviews with political leaders and experts, and the analysis of primary sources produced by the institutions studied, as well as official declarations and press reports.

Enlargement perceived as the Europeanisation of political representation structures 
While speaking of the impact of EU enlargement, we apply the term Europeanisation to the analysed empirical processes. Although Europeanisation may seem a somewhat catchall term, it applies to the impact of the European networking mode of governance on political representation groups in CEEC. We opt for a definition which conceives Europeanisation as "an incremental process, reorienting the direction and shape of politics to the degree that EC political and economic dynamics become part of the organisational logic of national politics and policy-making"26. Claudio Radaelli refined the definition of Europeanisation as "a process of a) construction, b) diffusion, c) institutionalisation of rules, procedures, paradigms, styles, ways of doing and shared beliefs and norms, formal and informal, defined and consolidated first in the decision-making process of the EU and then incorporated in the logic discourses, identities, political structure and policies at the domestic level"27.

Drawing on the available analyses of the Europeanisation of interest representation structures in the candidate countries ${ }^{28}$, I define Europeanisation as: a) The adoption by the political party elites of fundamental values and network consultation mechanisms, compatible with the patterns embedded in the European party system; b) The perception by these individuals of European institutions as an interest representation arena.

Two general questions are asked in this paper: 1.) What is the impact of the enlargement process on the interest formulation and international networking activity of party decision makers? 2.) What are the mechanisms of change, and how are norms interiorised? While analysing the ongoing change in political elites' identities and perceptions entailed by EU enlargement, the paper focuses on actors which take an active part in this process.

\section{Enlargement of European party structures - between socialisation to European norms and a rational strategy}


The process of the association of new parties to the transnational party federations may be analysed using contributions dealing with the role of norms in policy change. In recent years, authors concerned with institutional analysis provided evidence of a profound connection between rationality and norms. Martha Finnemore and Kathryn Sikkink speak of "strategic social construction', in which actors strategize rationally to reconfigure preferences, identities or social context". In fact, norm entrepreneurs act rationally, whereas rational choice may produce social knowledge. Thus, the debate is not about the predominance of rational choice or ideational change, but "about the role that choice plays in norm-based behaviour, about what motivates choice, and about the role persuasion plays in normative process and how to treat it ${ }^{, 29}$.

March and Olsen's institutionalist perspective for international change offers a framework explaining the connections between the logic of expected consequences - based on exogenous preferences and interest calculations - and the logic of appropriateness - based on endogenous identity, cognitive dimensions and rules. As both logics coexist in influencing political decisions, their relationship may be conceptualised in one of the following models:

1. The clearer logic dominates the less clear one;

2. Each logic corresponds to major decisions and minor refinements;

3. There is an evolution from one logic into the other;

4. One logic is a variable of the other ${ }^{30}$.

The periods of "critical juncture", such as the end of the Cold War, provide opportunities to contest existing ideas about political order. Such overtaking by new ideas may also be interest-based, as ideas and interests are interconnected: “embedded identity constructions (...) 
define the boundaries of what elites perceive to be legitimate ideas - thereby constituting their perceived interests. On the other hand, perceived interests define which ideas political elites select in their struggle for power among those available to actors" ${ }^{\prime 1}$. Once a norm or rule becomes consensual, it may be internalised and institutionalised. This may happen in the process of social learning, when actors acquire new interests and preferences through interaction with a broader institutional context ${ }^{32}$. The likeliness of social learning grows where individuals of a group share common professional backgrounds, interact regularly, and face a context of crisis but remain insulated from direct political pressure.

The activity anticipating EU enlargement at the level of European party federations provides an empirical illustration of the abovementioned postulates. The dissolution of the Soviet Bloc brought European political parties in search of interlocutors and potential partners in the emerging political families of CEEC. Both Socialist and Christian-Democratic International, as well as the European party federations and the national parties multiplied delegations in the region, aiming at building contacts and gathering information about the ongoing evolutions, but also testing the ground for future cooperation ${ }^{33}$. A number of initiatives facilitating the socialisation of new members to European norms, rules and values were undertaken, such as training on electoral campaigns or the functioning of political parties, material aid, but also invitating the new partners to party congresses and the creation of political forums such as the European Forum for Democracy and Solidarity, an informal structure linked to the Party of European Socialists.

\section{The association of new member parties in the institutional sociologist perspective}

The formal association of new members to party federations began in the second half of the 1990s, with the first signs of the stabilisation of CEEC party landscapes and the consolidation 
of the reform process. Launching the formal enlargement process with the Copenhagen European Council and the first applications for membership provided serious incentives to EU national parties and their federations to switch from dialogue to cooperation with potential partners. Thus, the European People's Party opened the way to the accession of new members during the 1995 Madrid Congress. According the associate status means the ultimate stage of the legitimisation of an applicant party, which becomes a full member when the enlargement is fulfilled. In July 1996 in Luxemburg, the EPP Political Bureau established a list of criteria relative to the stability and solvability of the candidate party on one side, and the sharing of common values and ideological loyalty on the other. Thus the applicant candidate party was expected:

1. To represent a stable political force (i.e. to have won at least $10 \%$ of the votes at the last parliamentary elections or 5\% during each of the last two elections;

2. To avoid splits during the two years preceding the acceptance;

3. To have paid the EUCD membership fees;

4. All the representatives of the candidate party had to be members of the EPP group at the Parliamentary Assembly of the Council of Europe, the Western European Union and other European representative institutions;

5. To include in its programme a particular commitment to European Integration on a federal model, individual rights, a social market economy and the principle of subsidiarity ${ }^{34}$.

\section{Organisational and political adaptation}

These criteria mark a starting point for intensive exchanges between parties from the EU and from CEEC. It meant a broad transfer of know-how to central European party elites on the functioning of European institutions, during delegations, traineeships and common seminars. 
According the observer status by the European People's Party since 1996, the associate member status since 1998 required clarifying the candidate party structures (such as defining the responsibilities incumbent on the general secretary, secretary responsible for international affairs or the press spokesperson). Socialisation occurs through the exposure of CEEC party leaders to information flows and dialogue forums accessible to full members. By integrating these networks, party leaders gain access to regular information letters and publications, as well as the invitation to participate or at least assist at Congress, Council, or Political Bureau meetings, as well as the standing working groups (such as the working group on EU Enlargement). The necessity of the federation's coherence explains the request of loyalty by joining the EPP groups in different European institutions.

\section{The importance of norms}

Joining the European People's Party means accepting its statutes and respecting the political criteria. Member parties are asked to support EPP positions in the political decisions taken on the domestic level (EPP status, art.3). This rule exposes new members to a normative framework of common understandings of ways of doing. The ideational set-up of the criteria transforms the 5-th condition relative to European integration, federalism and social market economy values $^{35}$ into a kind of evaluation grid for new candidates. Practically, common expectations of European parties could encompass the commitment to European integration or minority protection. The criteria relative to democracy, the rule of law and human rights are part of the general conditions established by the EU during the pre-accession stage, although it is sometimes difficult to measure their fulfilment in the absence of clear criteria ${ }^{36}$. Moreover, the Commission's avis concentrate mainly on economic conditions and legal transfers required by the acquis communautaire. 
It may be argued that European party federations carried out an in-depth survey of their partners' effective norm commitment. The evaluation reports sent from partner organisations implemented in CEEC (such as the German political foundation) encompassed virtually the whole political spectrum, both government and opposition political parties. It must be noticed that these CEEC parties, whose strong commitment in favour of European integration and federalism is not in doubt, have been literally "pursued" (to use the words of an EPP representative) by the European party federations. When a potential member party respected all the normative criteria, the formal, technical barriers could be lessened. In the case of the Polish Union of Freedom (UW), for example, the observer member stage was bypassed for the first time (this stage was a non-written rule, however it had been observed till then). While not all UW members were part of the EPP group at the Parliamentary Assembly of the Council of Europe, this formality could be resolved a few months following the UW accession to the EPP, while in the case of other candidate parties failure to comply to this criterion could interrupt the association process. We may say that in this case that norm compliance logic was the rule and precondition of calculation, while rational calculation accounted for minor refinements.

\section{Applying conditionality}

Conditionality - the most frequently evoked feature of the enlargement mechanism - is present in a latent way in the association process of new members to European party federations, through the establishing of application conditions. However, the use of threats - whether of a social or a material kind - in case the potential candidates do not comply to the rules, seems to have been rather exceptional. Threats of interrupting dialogue and thus delegitimising a CEEC partner were used with regard to parties whose democratic commitment was questionable. Constraint was applied regarding the Latvian party for Homeland and Freedom TB/ LNNK 
after its application in 1999. The party leaders' commitments were examined carefully, for example regarding their attitude towards the Meciar regime in Slovakia and minority protection. The EPP's working group Central and Eastern Europe announced that if the TB/LNNK voted against the law guaranteeing minority rights to Russians living in Lithuania, the EPP would cease its contacts with the party ${ }^{37}$.

Another means of pressure are long waiting periods, during which political leaders from candidate parties perceive they are tested regarding the internal functioning of their parties and their commitment to common values. This was the case with some conservative parties in CEEC, but also with post-communist parties, which had to go through a sort of quarantine immediately after 1989 before joining the club of social democracy ${ }^{38}$.

It appears that the transfer of norms may obey different mechanisms, ranging from teaching to various kinds of persuasion and even threats. The party federations may be perceived as teachers of norms ${ }^{39}$ or socialising institutions ${ }^{40}$, which create meanings and promote specific concepts about the role of the state, human rights, EU governance etc. There is no evidence in our case that material bargaining dominated the enlargement process. Rather, legitimating and associating new party members from CEEC involved the activities of teaching and persuasion, through the multiplicity of delegations, forums and seminars.

\section{The association of new party members in a rationalist-institutional perspective}

According to the logic of expected consequences, the party federation enlargement process may also be considered as a range of bargaining, resulting in a compromise that reflects the interests of each side. In fact, internal and external party observers often advance rational calculation based on material criteria (the relative size and power of parties and federations) as the essential factor explaining the association policy pursued in the 1990s. 


\section{The power calculation within transnational interactions}

After the deception of their initial aims (associating the historical social-democratic parties from CEEC or the Christian democrat parties based on the western model), the European party families had to lower their expectations and adapt to the realities of the local political landscape. The rational objective meant associating as much strong parties as possible, in order to enforce the federations' bargaining weight and resources once the enlargement was accomplished. Thus, say certain, the weight of the CEEC parties on the national scene was the prevailing factor influencing the dialogue. Contacts with some CEEC conservative parties were pursued notwithstanding the objective criticisms that could be made regarding their structure (the dominant role of trade unions in the case of Polish Social Movement Solidarity RS AWS) or their ideational engagement (like the question of the lack of engagement in favour of federalism). The power calculation may in fact have prevailed in the case of the Hungarian FIDESZ, which was initially a member of Liberal International, before applying to the EPP. FIDESZ was pursued actively by representatives of EPP member parties and it received a favourable opinion of the EPP Political bureau, while its statutes still situated the FIDESZ in the Liberal International, of which Victor Orban carried the vice-presidency. It may be said that the framework of conditions and waiting periods (such as the observer statute) was used as an instrument to delay the accession of parties, which were not judged as being of strategic interest by the EPP.

\section{Bilateral exchange of resources}

According to rational logic, the European party federations may be considered as formal institutions providing the applicant party leaders with material and ideational resources that enable them to exploit favourable occasions for the evolution of their activity both on national 
and on European levels. Representatives of the EPP were a source of legitimacy and of international contacts for the CEEC political leaders. International legitimacy, factor of the national legitimacy and the need for social esteem are important motivations of the adaptation to norms ${ }^{41}$. During the pre-accession period, the European Union gradually became an arena of interest representation for the candidate states ${ }^{42}$. CEEC parties sought to get associated into party federations, which carry weight in the European Parliament ${ }^{43}$.

Also for the leaders of European party federations, the contacts with CEEC became a necessity in the context of the legitimacy crisis they underwent. For example, the party summits organised in candidate countries by the EPP are a media event and they serve the image of the federation, while the summits held in Brussels remain rather unnoticed. Opening to the new, often governmental, conservative parties in CEEC represented an opportunity for the European Christian Democrats to try and counter the decline they underwent in the second half of the 1990s.

\section{The relationship between the two institutional logics}

The association of new parties to European federations allows observation of the correlation between the strongly intertwined logic of consequentiality and the logic of appropriateness. In fact, the logic of persuasion and of norm diffusion is often based on rational calculations.

The European party federations may be conceived as institutions ${ }^{44}$ with their own rules and complexity that change, adapting to the new circumstances. The empirical evidence confirms our initial hypothesis, according to which both logics co-exist and are mutually dependent. Following the framework proposed by March and Olsen, I concentrate on the $2^{\text {nd }}$ and the $3^{\text {rd }}$ model, which seem the most pertinent for our case study. The subjective qualification of the first model proposition ("the clear logic dominates the less clear") fails to be precisely defined, as it may concern both the perceptions of actors and of analysts. In fact, it seems 
difficult to define what a "clear" logic is as opposed to an "unclear" one. The $4^{\text {th }}$ proposal, suggesting that there is rather a difference in degree than in kind between the two logics seems too undifferentiated, considering that a clear distinction between the two logics may still be drawn.

Instead, the model suggesting the simultaneous existence of both logics, during which one dominates the other $\left(2^{\text {nd }}\right.$ model $)$, seems perfectly applicable in our case. Also the developmental proposal ( $3^{\text {rd }}$ model) should find its place in the analysis, as it allows for following the dynamics of the process, in which perceptions of interests and priorities are not externally defined and given. On the contrary, they develop and interchange with each other.

Thus, it may be argued, the association of new member parties to transnational federations may be perceived as a result of rational calculation: the will to tie links with potential strong allies. However, other elements interfere, relative to identity, such as the establishment of adhesion criteria. In some situations these criteria may dominate the rational ones.

The enlargement of European party federations may also be defined as a principally normbased process. When focusing on the normative logic does not bring the expected results, the other logic may be called for (as it was the case with the initial focalising on the ideologically nearest families in CEEC). Thus, European party federations used new categories and innovative procedures in order to realise the enlargement to CEEC parties. Still, the basic norms (commitment to democracy and European integration) remained unchanged.

\section{The actors of political enlargement - empirical evidence}

Having drawn the main analytical lines of the enlargement process seen through the prism of political parties, this part should illustrate the mechanisms of change while focusing on agents participating in identity redefinition. German political foundations are publicly supported 
organisations, which have close links to the German political parties ${ }^{45}$. Owning representation bureaus both in Brussels and in the candidate states, they can be considered as important channels transmitting norms and values, but also political contacts. Their transnational activity at the European level distinguished them from other political organisations originating from EU countries ${ }^{46}$. The activity of political foundations may be analysed through the double prism of the Europeanisation of political parties: creating channels of transmission of a political culture; influencing the perception of the European Union by the candidate state political leaders as an interest representation arena.

While during the first half of the 1990s, the German engagement in CEEC concentrated on direct support for structural reforms and know-how transfer, entering the official preaccession process entailed a growing focalisation on EU matters. It appears that nongovernmental actors such as the German political foundations supported the process of norm compliance of EU enlargement using, however, the normative arguments appealing to identity construction (teaching, persuasion) rather than social and material conditionality. Unlike in the accession negotiations, the point was not to obtain compliance with stable, legal frameworks, but to find reliable political partners and to familiarise them with the political mechanisms of EU functioning.

\section{Transmitting political culture. Foundations as agents of change.}

Affiliated with the German Christian-Democratic Union, the Konrad-Adenauer-Stiftung (KAS) cooperates with the European People's Party in matters of international party dialogue. During the 1990s, the expertise of the KAS helped the EPP - through the intermediary of the German CDU - to follow the political evolutions in CEEC.

Owing to their continuous presence in Central and Eastern Europe, foundation representatives could play an important role as intermediaries to transnational party contacts. They sent 
reports to party federations, informing them about the situation in CEEC, the evolution of the party landscape and details of internal tensions in local political parties. The direct and informal contact, particularly dense between the KAS, the German CDU and the EPP, consisted in exchanging opinions about the liability and readiness of an observed CEEC party to become a political partner on its own. During the association procedure, foundations' expertise allowed, among other things, sending a positive signal to the EPP about a CEEC political party. This was the case with helping Mikulas Dzurinda in Slovakia to offer a democratic alternative to the Meciar regime.

The information flow was bilateral. The activity of the German political foundation in Central Europe countries may be conceptualised as initiation to EU governance. This consisted in bringing their political partners into direct contact with European party federations, exposing them to the political forums surrounding the EPP, finally transmitting the bases of ideological commitments of European party families, the current discussions and reform projects. The Konrad-Adenauer-Stiftung representatives informed their partners in the candidate countries about the recent evolutions of the European People's Party. They promoted the values and positions of the Christian-Democrat federation and encouraged their interlocutors to apply to the EPP. Finally, they organised political meetings in Germany and abroad, thus creating structures of informal communication at a period where formal structures for dialog were not yet fully available.

The German political foundations may be considered - according to the sociologicalinstitutionalist perspective - as "norm entrepreneurs", which persuade their partners to redefine their identities and interests by engaging in a social learning process ${ }^{47}$. But it was also owing to the fact of representing the transnational network of European party federations that German foundations could promote ideas of European integration, federalism, 
subsidiarity or minority rights, knowing they could occasionally make use of conditionality arguments in order to achieve their objectives ${ }^{48}$. While participating in the enlargement process of the European party federations through the association of CEEC political parties, foundation representatives helped their partners adapt to the changing opportunity structure of the European Union. According to the KAS in Warsaw, its cooperation with organisations closed to political parties, especially the youth organisations, "has positively influenced the development of the Centre-Rights parties and was an important element by the association of the Union of Freedom (UW), the Conservative People's Party (SKL) and the Social Movement AWS (RS-AWS) to the European People's Party" ${ }^{\prime 4}$. Thus, German political foundations may be considered as intermediaries in the transfer of a political consultative culture between the EU parties and the CEEC ones.

The pre-accession period allowed building of personal relationships based on trust important factors in political communication. "Over the years of attending meetings, working groups, congresses, seminars etc, people had got to know one another - who you could trust, who you could not trust, who you fundamentally agree / disagree with. This clearly helped the transition along"

Network building. Foundations as intermediaries and mediators in contacts with European institutions

The Enlargement Forums organised by the KAS in Berlin are an example of the networking practice: they gather political leaders from CEEC together with EPP representatives, but also important representatives of the European Commission, and other institutions concerned with the Eastern enlargement. Thus, the Konrad-Adenauer-Stiftung became a kind of arena for socialisation for the candidate country political and administrative elites. Also in matters concerning the dialogue with non-candidate post-soviet states, common KAS-EPP meetings 
take place in the CIS, such as the pan-European forum organised in Kiev: "this dialogue could not have been organised without the assistance of the KAS Kiev office" ${ }^{\text {"51 }}$. It may be said that in contacts with partners from CEEC in the 1990 s, the German political foundation formed an essential part of the expertise and network building on behalf of the European party federations. Networking was not only the message, but also the means of the teaching process. By their activity, foundation representatives helped the CEEC political leaders to perceive Brussels as an arena of negotiations and of searching for political support.

Foundation representatives worked as intermediaries between European institutions (Parliament, Commission) and their partners in CEEC. They facilitated access to European interlocutors. Numerous seminars and research delegations influenced not only the know-how and professionalism but also, indirectly, the domestic legitimacy of Central European political elites. In Poland, the Friedrich-Ebert-Stiftung supported the strengthening of socialdemocratic expertise on European affairs, structural funds management etc. The FES financed a series of reports on Poland's advancement in fulfilling the Enlargement criteria. The official presentations of these "EU Monitoring" reports in Brussels allow both the presentation of a critical, insider's view to the Commission, and the positioning of the Ebert foundation, but also opening influential channels to Polish experts ${ }^{52}$. When in 2001, Leszek Miller, the leader of the (then oppositional) Union of Democratic Left (SLD) went to Brussels to express his view on the enlargement negotiations, it was perceived by his interlocutors in the Commission as getting in contact with the probable future prime minister. At the same time, it had important domestic repercussions on Polish politics, media, and eventually public opinion.

The activities of the European Forum for Democracy and Solidarity are organised essentially by social democratic foundations. While a coordinator is named at the level of European Parliament to manage this light structure, a decentralised network organises training and 
conferences associating CEEC party leaders and representatives of the Party of European Socialists. This kind of delegation of political contacts to a non-partisan, transnational body appears to be a necessity for the PES: "The pre-elections support for the CEEC social democratic parties is a very important activity of the European Forum. - This is something that we in the PES are simply not equipped to provide for the CEEC parties, at least not as material assistance. I am very happy that this is done by the Forum, and that it associates the PES in its work as it is truly a forum for coordination between different parties and foundations. This is the way to share the responsibility for the transition country parties observers to the PES between us and the European Forum"s3.

Let us note that the networking activity of the foundations and their facilitation of access to European arenas was decisive in the second half of the 1990s, before the advancement of accession negotiations. Since that time, the net of contacts of all kind between CEEC political leaders and their European interlocutors grew and the political foundations are no more considered as essential information sources or intermediaries for transnational contacts. However, this channel of transnational communication played an important role in the preaccession period.

\section{The impact of the norm transfers in the direction of CEEC parties}

It appears difficult to isolate the impact of the European party organisations' networking on the perceptions of CEEC party leaders during a process that we consider to be based on interactions. The candidate states reoriented their politics and economies in the direction of the European Community at the beginning of transformation process. Searching for international recognition, they looked for contacts to important party federations. During the association process, they had to prove their commitment to a common set of norms and 
values, clarify their structures, prove to be reliable interlocutors, and ideally provide proof of their commitments through political decisions taken during their governmental activity. Obviously, the process of EU enlargement as a whole (again, it is hard to establish a hierarchy between the intervening factors) influenced both the formal structures, discourses and the behaviour of political elites. While composing their party manifestos and programs, Central European conservative party leaders based their declarations on the European Peoples' Party, which served as a kind of blueprint. They adopted general discourses stressing their attachment to European liberal values. Still, translating discourses into political decisions may prove complicated. Even if European party federations are party-like organisations, they cannot be considered as effective political parties; the domestic parties which compose them are characterised by an important degree of ideological heterogeneity and domestic political context and strategies.

While acknowledging the diversity of Western European parties is evidence ${ }^{54}$, this is not always the case with research on CEEC parties. Questions asked in research designs dealing with applicant states are often dichotomist, simplifying or normative (like trying to determine the general allegiance to "Western" values, to "Europe", or its absence). They do not reflect the essence of the bargaining position of a party, whose leaders try to use an opportunity window at the European level, while taking into account the pressures at the domestic level. The critical phase of accession negotiations requires more differentiation by analysing discourses, commitments and political decisions of Central European political party leaders, which can be studied with similar instruments to their Western sisters.

\section{Conclusion}

The association of political parties originating from the candidate states to European party federations gave way to normative pressures aiming at the overtaking by the applicants of a 
set of values, styles and ways of doing. This paper tried to illustrate and explain the way in which the rational "logic of consequentiality" interferes with the "logic of appropriateness" in the process of socialisation and differential empowerment, both essential components of the EU-induced change. The kind of EU governance CEEC experienced gave way to greater openness of the party leaders to discussions and bargaining in an international context. Participating in a row of European forums and councils gives the CEEC participants a glimpse of belonging to the community and discussing among equals. The importance of these socialising forums should not be underestimated. Their absence could make the process of liberalisation and opening of political CEEC countries much longer.

This article tried to illustrate the mechanisms in which informal rules and norms embedded in the European transnational party networks are diffused to the political parties from CEEC. Transfers are not unidirectional. The Eastward enlargement will probably affect the way decisions are taken at the European level, how political and regional coalitions are built, ideas are diffused and enclosed in political programs. This reality seems present now in the mind of European party decision makers: "EU states had to sit up and realise that this is just another part of Europe, not really too faraway, and in a relatively short period of time, these people will have representatives sitting in the European Parliament, requesting finance, contributing to decisions and, horror or horrors, getting a seat at the Commission and at the Council tables"

To conclude, some criticisms will be advanced concerning an exclusive focalising on conditionality. It is not to contest that conditionality holds an important place in the enlargement process. Still, it seems that: 
1. The concept of Conditionality reduces enlargement to a unilateral transfer, where the applicant side has no room for manoeuvre. It imposes reasoning in terms of rewards, promises, punishments and threats, reducing the complexity of Central and Eastern European institutions into a kind of Pavlov's dog reactivity.

2. It omits differentiation, taking into consideration the local context, internal factors like the pressure of Central European interest groups, which CEEC decision makers have to take into account. Stating a general weakness of civil society in CEEC may sometimes prove a nice way to leave aside the necessity of considering societal channels of influence. However, it would be too simple to consider the CEEC governments as cut from any societal interests. On the contrary, applicant country governments constantly struggle with the difficult task of persuading their electorate to accept the social consequences of the transformation as a necessary stage of enlargement.

3. Conditionality should not lead us to overestimate the EU impact on transformations. After the initial neglecting of external factors in transformation research ${ }^{56}$ during the $1980 \mathrm{~s}$ and their revalorisation during the $1990 \mathrm{~s}^{57}$, we should not reach the other extremity while explaining democratisation exclusively as the result of external/European pressures. In a nutshell, in 1989 it was not only the European Community, which turned to the new democracies from Centre-East. These democracies under construction turned resolvedly towards the West and their political leaders did not hesitate to exercise pressures if they felt a lack engagement on the side of the $\mathrm{EC}^{58}$.

The ongoing accession procedure focalises our attention on the conditionality dimension. However, keeping in mind the logic of appropriateness may preserve us from some mental 
shortcuts. Focusing on interactions allows adherence to conditionality as the major explaining factor of the EU-induced change to be overcome.

\section{Notes}

\footnotetext{
${ }^{1}$ For an analysis of the concept, see W. Jacoby, Imitation and Politics. Redesigning modern Germany, (Ithaca, NY: Cornell University Press, 2000).

${ }^{2}$ A. Héritier, D. Kerwer, C. Knill, D. Lehmkuhl, M. Teutsch, A-C. Douillet, Differential Europe. The European Union Impact on National Policymaking, (Oxford: Rowman\&Littlefield, 2001).

${ }^{3}$ See M. Finnemore, K. Sikkink, 'International Norm Dynamics and Political Change', International Organization, 52(4) Autumn 1998, pp. 887-917; J. T Checkel, 'Social construction and integration', Journal of
} European Public Policy, 6(4) 1999, pp. 545-560, M. Marcussen, T. Risse, D. Engelmann-Martin, H. J. Knopf, K. Roscher, 'Constructing Europe? The evolution of French, British and German nation state identities”, Journal of European Public Policy, 6(4) 1999, pp. 615-633.

${ }^{4}$ F. Schimmelfennig, 'Liberal Norms and The Eastern Enlargement of the EU: A case for Sociological Institutionalism', Austrian Journal of Political Science, 4, 1998, pp. 459-472.

${ }^{5}$ For the distinction, see C. M. Radaelli, 'Whither Europeanization? Concept stretching and substantive change', European Integration online Papers (EIoP), 4 (8), 2000 http://eiop.or.at/eiop/texte/2000-008a.htm. p. 16.

${ }^{6}$ U. Sedelmeier, 'Accommodation beyond Self-Interest: Identity, Policy Paradigms, and the Limits of a Rationalist Approach to EU Policy towards Central Europe', in S. Saurugger (ed), politique européenne, (3) January 2000, pp. 13-37.

${ }^{7}$ R. Cécile, 'La Commission européenne face à l'élargissement de l'Union à l'Est: la construction d'un leadership', in S. Saurugger (ed), politique européenne, (3) January 2001, pp. 38-60.

${ }^{8}$ U. Sedelmeier, H. Wallace, 'Eastern Enlargement. Strategy or Second Thoughts?', in: Wallace Helen, Wallace William, Policy-Making in the European Union, (Oxford: Oxford University Press, 2000).

${ }^{9}$ For a description of institutional limitations, see C. Lord, 'Les parties politiques et l'Union européenne. Quel type de concurrence imparfaite?', in P. Delwit, E. Külahci, C. Van de Walle (eds), Les fédérations européennes des partis. Organisation et influence, (Brussels: Editions de l’Université de Bruxelles, 2001); also L. Bardi, 'Transnational party federations, European Parliamentary Groups and the Building of Europarties', in R. S. Katz, 
P. Mair (eds), How Parties Organize: Change and Adaptation in Party Organization in Western Democracies, (London: Sage, 1994).

${ }^{10}$ Treaty on European Union, Article 138a - "Political parties at European level are important as a factor for integration within the Union. They contribute to forming a European awareness and to expressing the political will of the citizens of the Union".

${ }^{11}$ S. Hix, 'Parties at the European Level and the Legitimacy of EU Socio-Economic Policy', Journal of Common Market Studies, 33 (4) December 1995, pp. 527-554.

${ }^{12}$ S. Hix, C. Lord, Political parties in the European Union, (Basingstoke, Hampshire: Macmillan, 1997), p. 1.

${ }^{13}$ Hix, Lord, Political parties, p. 3

${ }^{14}$ Hix, Lord, Political parties.

${ }^{15}$ R. Ladrech, 'Political Parties and the Problem of Legitimacy in the European Union', in T. Banchoff, M. Smith, Legitimacy and the European Union. The contested polity, (London: Routledge, 1999), p. 100.

${ }^{16}$ Hix 'Parties at the European Level', p. 540, see also O. Niedermeyer, Europäische Parteien? Zur grenzüberschreitenden Integration politischer Parteien im Rahmen der Europäischen Gemeinschaft, (Frankfurt: Campus, 1983).

${ }^{17}$ Ladrech 'Political Parties', p. 99.

${ }^{18}$ Hix 'Parties at the European Level', pp. 544-547.

${ }^{19}$ Ladrech 'Political Parties', p. 104.

${ }^{20}$ See K. M. Johansson, 'Vers une théorie des fédérations européennes de parties', in Delwit, Külahci, Van de Walle (eds), Les fédérations européennes de parties. For reasons of feasibility, this paper concentrates on the enlargement of European party federation Eastwards and the role of German political foundations as intermediaries in this process. It is clear that the activity of domestic parties as well as of European party groups is horizontally bound to this network.

${ }^{21}$ Checkel, 'Social construction and integration'.

${ }^{22}$ For a contribution bringing the domestic context back in, see G. Pridham, 'EU Accession and Domestic Politics: Policy Consensus and Interactive Dynamics in Central and Eastern Europe', Perspectives on European Politics and Society, 1(1) 2001, pp.49-74.

${ }^{23}$ Hix, Lord Political parties. 
${ }^{24}$ Some authors try to study this relationship, see A. Roger, 'Perspectives d'intégration à L'Union européenne et formation des systèmes de partis dans les pays d'Europe centrale', in: S. Saurugger (ed), politique européenne (3) January 2001, p. 86-113.

${ }^{25}$ See Marcussen ‘Constructing Europe?’, p. 614-633.

${ }^{26}$ R. Ladrech, 'Europeanization of Domestic Politics and Institutions: The Case of France', Journal of Common Market Studies, 32 (1), March 1994, pp.69-89, p.69.

${ }^{27}$ C. Radaelli, ‘Whither Europeanization?', p. 4.

${ }^{28}$ D. Fink-Hafner, 'The role of Interest Organisations in the Europeanisation of Slovenian Policy-Making', Journal of International Relations (Issues of Politic, Law and Economy), 4 (1-4) 1997, pp. 130-147, N. PerezSolorzano Borragan, 'Organised Interest in Central end Eastern Europe. Towards Gradual Europeanisation?’, in S. Saurugger (ed), politique européenne, (3) January 2001, p. 61-83.

${ }^{29}$ Finnemore, Sikkink 'International Norm Dynamics', p. 917.

${ }^{30}$ J. G. March, J. P. Olsen, 'The Institutional Dynamics of International Political Order', International Organization, 52(4) Autumn 1998, pp. 943-969, pp. 952-954.

${ }^{31}$ Marcussen \& al., 'Constructing Europe?', p. 617.

${ }^{32}$ Checkel 'Social construction and integration'.

${ }^{33}$ For a useful empirical illustration, see P. Delwit, J-M. de Waele (eds), La Démocratisation en Europe centrale. La coopération paneuropéenne des partis politiques, (Paris: L’Harmattan, 1998).

${ }^{34}$ EPP Yearbook '99, (Brussels: EPP Group of the European Parliament, 2000).

${ }^{35}$ The values of the German Christian Democratic Union, EPP's strongest party, are perceptible.

${ }^{36}$ H. Grabbe, K. Hughes, Enlarging the EU Eastwards, (London: RIIA, Chatham House papers 1998). See also on the tensions linked to enlarging the European governance to the East, H. Grabbe, 'How does Europeanization affect CEE governance? Conditionality, diffusion and diversity', Journal of European Public Policy, 8(6)

December 2001, pp. 1013-1031.

${ }^{37}$ This is what happened. EPP Yearbook '99, p. 333.

${ }^{38}$ The Polish post-communist social democrats became fully legitimate interlocutors only after their admission to the SI.

${ }^{39}$ M. Finnemore, 'International Organizations as teachers of norms: the United Nations Educational, Scientific and Cultural Organization and science policy', International Organization, 47(4) Autumn 1993, pp. 565-597. ${ }^{40}$ March, Olsen ‘The Institutional Dynamics’, p. 964. 
${ }^{41}$ Finnemore, Sikkink 'International Norm Dynamics', p. 902-904.

${ }^{42}$ See Perez-Solorzano Borragan, 'Organised Interest in Central end Eastern Europe'.

${ }^{43}$ Notwithstanding with this tendency, the decision to ask the association to a transnational party federation was often the result of strong controversies inside central European party presidencies, whose leaders' representations of ideological identity diverged.

${ }^{44}$ According to March and Olsen's definition 'a relatively stable set of practices and rules defining appropriate behaviour for specific group of actors in specific situations', p. 948.

${ }^{45}$ For more analytical data on the German political foundations, see Dorota Dakowska, Comment approcher le rôle des fondations politiques dans la politique étrangère allemande? L'exemple de la Pologne dans les années 1989-1999, working paper n5, 2001-3 (May), Berlin, Centre Marc Bloch.

${ }^{46}$ We concentrate here at the two major German foundations: the Konrad-Adenauer-Stiftung, which has close links with the Christian Democratic Union and the Friedrich-Ebert-Stiftung (close links with the Social Democratic Party). Partially following the German example, most of European states and parties have created their own political foundations, such as the Eduardo Frei Foundation and the Alfred Mozer Stichting in the Netherlands, the Olof Palme International Center in Sweden, the Karl Renner Institut in Austria. However, the financial resources of most of the foundations make a comparison with the German case difficult.

${ }^{47}$ See T. Börzel, T. Risse, 'When Europe Hits Home: Europeanization and Domestic Change', European Integration Online Papers, (EIoP), 4(15) 2000, http://www.eiop.or.at/eiop/texte/2000-015a.htm, p.10.

${ }^{48}$ As the political communication in the pre-adhesion period is based on interactions, it should also be asked what resources this activity brought to German actors, at both national and European levels. This is however a matter for another paper and will not be debated here.

${ }^{49}$ R. Freudenstein, Die Arbeit der Konrad Adenauer Stiftung in Polen - Bilanz und Perspektiven, (Warsaw: KAS, 23 January 2001).

${ }^{50}$ Interview Brussel 2001.

51 'EPP/CDI Central and Eastern Europe working group, EP, Brussels 11 November 1999', in EPP Yearbook 99', p.327.

${ }^{52}$ Some of who became Ministers and counsellors to the social-democratic government in Poland, in Autumn 2001. See J. Hausner, M. Marody (eds), The quality of Governance. Poland Closer to the EU?, EU Monitoring IV (Warsaw: FES, 2000). 
${ }^{53}$ J-F. Vallin, General Secretary of the Party of European Socialists and a member of the Steering Committee, in Annual Report 1995, 'Cooperation with the PES',

http://www.europeanforum.net/library/reports/annual95/pes.htm

${ }^{54}$ Héritier \& al, Differential Europe.

${ }^{55}$ Interview Brussel 2001.

${ }^{56}$ P. C. Schmitter, G. O’Donnel, L.Whitehead, Transitions from Authoritarian Rule, t.1. A prospect for Democracy, (Baltimore: John Hopkins University Press, 1986).

${ }^{57}$ L. Whitehead, (ed.), The International Dimension of Democratization. Europe and the Americas, (NY: Oxford University Press, 1996).

${ }^{58}$ U. Sedelmeier, H.Wallace, 'Eastern Enlargement'. 